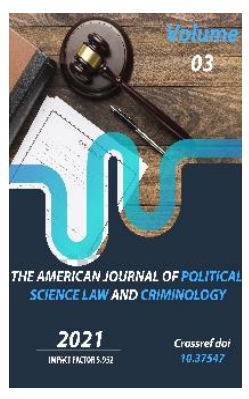

\title{
Diplomatic Protocol: Theoretical And Legal Approaches To Its Study
}

\author{
Sherzod Shukurovich Toshpulatov \\ LLB., LL.M., Candidate/2022, The Pennsylvania State University, The United States Of America, \\ 131 Sowers Street, Apt B6, State College, PA 16801, the USA.
}

Journal Website:

https://theamericanjou

rnals.com/index.php/ta

jpslc

Copyright: Original content from this work may be used under the terms of the creative commons attributes 4.0 licence.

\section{ABSTRACT}

The article illustrates the fundamental aspects of studies of diplomatic protocol from different perspectives and makes an effort to review its characteristics by relying on political or geographical positions of states. The article also defines the diplomatic protocol and what appeals to it by analyzing its theoretical and legal bases as well as presenting examples of documents used among members of the diplomatic corps. Considering the main features, the article makes a conclusion on the unique nature of the diplomatic protocol.

\section{KEYWORDS}

Diplomatic protocol; diplomatic missions; corps; scholars; diplomatic ceremonial; agrément; ambassadors; consuls; Charge d'Affaires ad interim; international law; conventions; legal basis; diplomatic correspondence.

\section{INTRODUCTION}

The Diplomatic Protocol may not be the most exciting area of international relations, but they create the atmosphere necessary for the activities of diplomatic missions. The protocol and the ceremonial contribute not only to the proper foreign manifestation of a state but 
especially to the quality of its relations to different foreign states.

\section{THE MAIN PART}

The diplomatic protocol finds its theoretical reflection in the works of several scholars as well as in several international and national regulatory acts. The essence of the definitions and concepts of the diplomatic protocol allows us to fully consider the various approaches to its study.

In foreign literature, there are various definitions of diplomatic protocol. For instance, the "Diplomatic Dictionary" gives the following definition: "A diplomatic protocol is a set of generally accepted rules, traditions and conventions observed by governments, foreign affairs officials, diplomatic missions, and other officials in international relations".

The Uzbek prominent scholar in the field of diplomatic protocol A.Rasulov in his book, "Diplomatic protocol, ceremonial, etiquette. Fundamentals, theory, practice", states that each state participating in international relations is characterized by its social system, history, traditions, culture and language. Normal communication between states would be impossible if the diplomatic protocol had not been formed in diplomacy and international relations as an important instrument. The protocol introduces into these relations common norms and rules, discipline and organization for all parties [1].

Mircea Malita states that protocol and ceremonial "can be considered true barometers that indicate the state of relations between countries" [2].
In turn, the Ambassador Extraordinary and Plenipotentiary P.F. Lyadov, Professor of the Department of Diplomacy of the Moscow State Institute of International Relations of the Ministry of Foreign Affairs of Russia, in his book "The History of the Russian Protocol" deepens the definition of a diplomatic protocol as follows: "The diplomatic protocol itself is the form in which other foreign policy affairs of the state, its representative office or representative operate. The rules of the diplomatic protocol are based on the so-called principle of "international politeness" - a set of generally accepted rules of international practice of etiquette, respect in interstate relations" [3].

A similar definition of the protocol is given by another well-known Russian Diplomat V. Semenov. Similar to Lyadov, Semenov focuses on the significance of the protocol as an integral part of practical diplomacy: "The protocol means a set of rules according to which official representatives in each country regulate the order of various diplomatic ceremonies. Protocol events are used in the development of numerous details, both extraordinary ceremonies and ceremonies related to the work of missions " [4].

Further, he reinforces his reasoning: "The protocol is observed during negotiations, drafting of agreements. In the political and administrative structure, the protocol gives everyone their place, guarantees all officials the opportunity to use their rules, settles controversial issues of seniority, as well as disputes concerning the privileges and immunities presented. In addition to the organization of ceremonies, the protocol also defines the methods, framework, behaviour and etiquette and establishes rules regarding 
official and personal correspondence, uniforms - all that provides each place and respect, corresponding to its official position and which are recognized by other political and administrative authorities and society." [4] This rather difficult to understand definition, presented by Semenov, mainly adds a hint of the interdependence of the diplomatic protocol with the practical side of diplomacy and vice versa.

All scholars devoted to the development of a diplomatic protocol can rightly be considered J. Wood and J. Serre. Their joint work "Diplomatic Protocol and Ceremonial", being a classic guide to protocol and ceremonial, is a kind of code of diplomatic politeness. They share the historical protocol and the protocol of modernity, advocating that the forms, methods and tools remain stable and unchanged. According to their interpretations, "at present, the protocol means a set of rules according to which in each country official representatives of the authorities regulate the order of various diplomatic ceremonies. Protocol rules are applied in the development of numerous details as extraordinary ceremonies related to the work of diplomatic missions" [5].

The well-known French diplomat Jules Martin Cambon in his book "Diplomat" tried to summarize the experience of his diplomatic activity, touching on the scope of the protocol. Cambon wrote that "The rules of the protocol now seem somewhat old-fashioned. However, the protocol requires to be observed in all senses" [6]. This is confirmed by the following case, described in Diplomat: "Before, when the ambassador arrived at his post, he was received with ceremonies. He was said to have made his entry. All the ambassadors went to meet him in their carriages and escorted him home. This ostentatious display of politeness most often served as a pretext for conflict, for each of these gentlemen challenged the right of others to occupy a more honourable place.

Diplomatic history is full of such quarrels. In 166 , in London, during the entry of the Swedish Count Wattevil, they quarrelled with the lackeys of the French ambassador, Count d'Estrada, and cut the lintels from his carriage; swords were fired and many French, Spanish and English were killed on the spot" [6].

Thus, citing such a vivid example, Cambon moves away from the traditional classical description of the protocol and tries to characterize it as a kind of impetus or cause for the deterioration of relations with any country, i.e. from its definition it can be concluded that the protocol is one of the most effective policy instruments in interstate relations.

The author of the Labor Guide on Diplomatic Practice, E. Satow, assigns even more primary importance to the diplomatic protocol, describing it as "a code of generally accepted rules that are mandatory for states and officials in international relations to comply with ... (and) which can be derogated on the authority of the state in the most unfavourable light, and also lead to undesirable international consequences" [7]. However, the statement of Satow cannot be called correct with certainty, because today the level at which diplomatic receptions are organized is always high and in most cases fully meets the basic requirement.

Based on the above definitions, it can be stated that a diplomatic protocol is a set of rules of conduct for states and their representatives on official and unofficial occasions, and in order to 
avoid a deterioration of the image or the appearance of any confusion, the state must comply with all the provisions of the protocol. To attach great importance to the strict organization of receptions and visits for the state means to secure a path to success and gain the trust and support of the guest state. In regards to the main functions of a diplomatic protocol, the following points can be stated.

Firstly, it provides the diplomat with a certain place, which allows delineating the line between compliance and non-observance of fundamental rights and obligations.

Secondly, it clearly regulates many controversial issues related to organizational issues, such as seniority issues, disagreements regarding privileges and immunities granted, etc.

Thirdly, an important function of the protocol is the definition of methods, frameworks, rules of conduct and etiquette, as well as the establishment of uniform rules for conducting correspondence and correspondence, uniforms, etc. Fourthly, thanks to the protocol, visits of officials, as well as their conclusion of agreements, pass with a touch of solemnity, which, in turn, makes it possible to create a relaxed and friendly atmosphere during receptions.

Therefore, it is extremely important to pay maximum attention even to the smallest details during the organization of receptions and visits, and the rejection or violation by an official of any rule can be perceived as a deliberate violation and disrespect for the receiving state. Moreover, this, as already mentioned above, can significantly worsen relations between countries, and even if the violation was done unintentionally, it would be difficult for the side that failed to find a way to correct the error.

The main subjects of the diplomatic protocol are the states and their official representatives. The main task of an official is to develop friendly relations between his state and the ruler of another state; therefore, a person sent with a diplomatic mission to a state must have an idea of the various distinctive features inherent in that state. The ambassador can start his main functions from the moment of the presentation of credentials, however, when establishing diplomatic relations for the first time and arriving in the country of accreditation, a group of diplomatic administrative and technical workers is sent, whose main task is to prepare the embassy for normal operation.

In international law, according to the Vienna Convention [14] on Diplomatic Relations of April 18, 1961, before the appointment of the head of a diplomatic mission, request an agrément (fr. "Consent"). The ambassador, completing his mission in this state, often makes farewell visits to officials of this government in order, to sum up, the existing relations and perhaps indicate prospects for strengthening relations in the future. Agrément, if there are no special considerations in the centre on this matter, it is more expedient to request through a diplomatic representative who leaves the post, which allows him to conduct additional useful work before leaving home [8].

The fact of the request of the agrément is not accepted to disclose, to avoid in case of refusal possible complications between the states and the corresponding comments of the third 
country and the press [8]. According to the Russian Ambassador Extraordinary and Plenipotentiary E. Kuzmin in his monograph "Diplomatic and business communication: rules of the game", "the disclosure of information about the fact of the request of agrément, leaks of information about refusal can damage the future career of a diplomat when he is appointed to another country" [8].

An integral attribute of a diplomatic protocol is the presentation of credentials by the ambassador. The credentials should be understood as an official document adopted in interstate practice, certifying the powers of the appointed diplomatic representative (ambassador, envoy) and handed to the head of state or the official representing him [9]. His certified copy is pre-transmitted to the head of the department of foreign affairs. The letters begin with the official, constitutional name of the head of state, which sends the ambassador. Then comes the full title of the head of the host state. There is a desire to appoint a new ambassador to further develop and deepen relations between the two countries.

Further, the first name, patronymic and last name of the ambassador are communicated and a request is made to believe everything that the ambassador will state on behalf of the head of his state and government. According to diplomatic experts, the ceremony of presenting credentials to a foreign ambassador all over the world is the first official contact with the head of state, and that is why in all countries the ceremony of presenting

\footnotetext{
${ }^{1}$ The diplomatic corps means the heads of diplomatic missions accredited in any state in the aggregate.
}

credentials is developed carefully and in detail [10].

So, having handed over credentials, the ambassador is considered authorized to embark on his mission. Active engagement begins with a series of courtesy visits by officials of the host country and colleagues heads of diplomatic missions. Usually, courtesy visits mean nothing more than giving attention to the person concerned and in no way discussing any important issues. According to the norms prescribed in the protocol after the presentation of credentials, the ambassador is the first to pay a visit to the diplomatic corps ${ }^{1}$ (diplomatic corps) only to ambassadors.

Visits of politeness are applied to the country's officials and heads of diplomatic missions at the same time, at several meetings per day. Based on the state of relations with any country, the ambassador can organize visits in order of importance: to postpone with some and speed up with those with which relations are most important for the policy of this state. The head of the diplomatic corps is the doyen (nuncio in some Catholic countries): he is a kind of mediator between the entire diplomatic corps and the state in which he is accredited.

The ambassador took on as a duty is obliged to respond to inter-embassy and inter-agency correspondence; in other words, the delay in sending diplomatic notes may be a sign of a bad tone and significantly affect the development of relations with the country.

It should be noted that the couple ambassadors make protocol visits. Often, 
meetings are organized with the spouses of heads of other diplomatic missions, as well as with women who occupy a prominent place in the social life of the host country. The participation of spouses of diplomats in various events can significantly increase the successful outcome of a diplomatic mission. However, as in other cases, such participation requires the necessary preparation - from general education and language to knowledge of the rules of etiquette.

With the final departure of the ambassador to his homeland, his successor simultaneously transmits his credentials to his predecessor along with his credentials. Letters of a recall are the official letter of the head of the state-envoy of a diplomatic representative to the head of state, who accepted the diplomatic representative, about the withdrawal of this representative from his post and the completion of his mission [11]. The preamble of revocable letters briefly reports on the fact of the withdrawal of the diplomatic representative, on the actual or officially nominated reasons for the recall, it is hoped that the diplomatic representative helped to maintain and develop diplomatic relations between the countries. Revocations are issued in the same way as credentials.

At the end of his diplomatic mission, the ambassador provides for several necessary activities. In some countries, the range of senior officials who receive farewell visits is determined based on the level of relations with the country, the nature of the relationship and the results achieved. On the day of departure, the ambassador may send a personal note to the foreign minister of the host country, which contains a notification of the departure of the ambassador and a candidature for the post of Chargé D'affaires. ${ }^{2}$

The theme of key state symbols is also inseparable from protocol issues: the coat of arms, flag, anthem. Showing them the necessary honours is one of the most solemn manifestations of international politeness. The basis of the international etiquette of the flag and the coat of arms is strict compliance in their production to the approved by law description, including individual parts and symbols. International experience shows that the leadership of the country attaches significance to the attitude in the manufacture of the flag since its sloppy appearance can damage the image of the state [8].

Moreover, state-level documents acquire power only when they bear the image of a flag and a coat of arms, are sealed with an official stamp, etc. When hanging the flags of several states, the size of the flags should be the same. Honorary is the extreme right place, and the most common practice is placing flags in alphabetical order of the names of states.

The international practise also implies a corresponding response to holidays, its character is determined by the state of interstate relations, the significance of the event and the local protocol. In most cases, there are welcome telegrams to the head of state or/and government, or the minister of foreign affairs. In addition to congratulations, these diplomatic documents contain an assessment of bilateral relations at the

\footnotetext{
${ }^{2}$ Charge d'Affaires ad interim - Charge d'Affaires ad interim head of diplomatic mission
} 
moment, wishes for their further development, and, if necessary, hope is being expressed that obstacles hindering cooperation will be removed [12].

On the occasion of the national day of their state, the embassies conduct official receptions. Sometimes, the arrival of theatre and musical groups, the opening of art exhibitions, etc. are timed to the holidays. According to E. Kuzmin, "a headache for ambassadors is visiting festive receptions by the leadership of the host country or their high representatives. For obvious reasons, the first persons (too many receptions are held in the diplomatic corps) evade participation, and the ambassadors are trying to "get" two or three members of the government, the foreign minister or at least his deputies" [8].

The demise of a state official implies sympathy and the direction of condolences at an appropriate level, and sometimes participation in mourning events. Often, the leaders of many countries gather at the funerals of prominent political and state leaders and, along with participation in official ceremonies, hold working meetings between themselves.

\section{RESULTS AND CONCLUSION}

In general, when it comes to choosing between protocol and policy, the emphasis is undoubtedly placed in the direction of the latter. Whatever the eloquent rules of the diplomatic protocol, the interests of politics dominate in any case. Proof of this can be the case described in the book of the Egyptian Diplomat F. Moussa "Diplomatic Protocol and His Organization": when in 1967 Soviet diplomat N. Podgorny, being a furious smoker, was preparing to pay a visit to the Vatican, he was hinted that smoking in the walls the Vatican prohibited. However, during the visit itself, after exchanging greetings, those present saw how Pope Paul VI himself kindly opened a snuff-box to Podgorny and offered him a cigarette [13]. Truly, the interests of politics are often much more important than the rules of a diplomatic protocol.

In terms of near-universal participation by sovereign States, the high degree of observance among States parties and the influence it has had on the international legal order, the Vienna Convention on Diplomatic Relations may claim to be the most successful of the instruments drawn up under the United Nations framework for a codification of several norms of diplomatic protocol.

The Vienna Convention provides a complete framework for the establishment, maintenance and termination of diplomatic relations on a basis of consent between independent sovereign States. It specifies the functions of diplomatic missions, the formal rules regulating appointments, request of agrément, declarations of persona non grata of a diplomat who has in some way offended, and precedence among heads of mission.

Although the above-mentioned provisions of the Vienna Convention address some aspects of the diplomatic protocol as its legal basis, it does not fully cover the norms and principles of the diplomatic protocol.

In regards to the experience of Uzbekistan in the field of diplomatic protocol, the role and functions of the Ministry of Foreign Affairs of the Republic of Uzbekistan can be an example of how diplomatic protocol work in practice. According to the Rules of Regulation of the 
Ministry approved by the Presidential Decree, the Ministry takes measures to provide information, diplomatic protocol and organizational support for visits by heads of state, government and other senior officials, as well as other politically significant international events [14].

At present, high-level meetings of the country's leadership and local authorities with foreign partners are being organized on a regular basis. This, in turn, requires adherence to the rules and principles of diplomatic protocol for the quality and high level of these events. However, the lack of a legal act or guidelines governing the rules of the diplomatic protocol has led to difficulties and problems in practice.

Although the Vienne Convention or the Rules of Regulation of the Ministry of Foreign Affairs may cover basic norms of diplomatic protocol, there are no legal acts regulating the principles and rules of diplomatic protocol, which can be used in different events at various levels.

Furthermore, despite the fact that in Uzbekistan the theoretical bases of the diplomatic protocol have been created to some extent such as the works of Rasulov A. [1], Abdullaeva L. [10], the law-making process has experienced a lack of legal instruments related to norms and principles of diplomatic protocol and etiquette.

In conclusion, taking into account the abovementioned characteristics of diplomatic protocol, it is proposed to elaborate a regulatory act on the diplomatic protocol in the form of Recommended Guideline in domestic legislation by considering both theoretical approaches and challenges in practice.
Creating a legal instrument will make a significant contribution not only to the development of diplomatic law but also to the efficacy of the ministries and agencies of Uzbekistan that directly operate with foreign partners.

\section{REFERENCES}

1. A.G.Rasulov. (2014). Diplomatic protocol, ceremonial, etiquette. Fundamentals, theory, practice: monograph. University of World Economy and Diplomacy. Tashkent: ART FLEX, p. [U-52570/2].

2. Malita Mircea. (1973). Diplomacy, schools and institutions, Didactic and Pedagogical Publishing House, Bucharest.

3. Lyadov P.F. (2004). History of the Russian Protocol. Moscow. International relations.

4. Semyonov V. (2002). The practice of diplomatic protocol and etiquette. International agency "A.D. \& T.".

5. Wood J., Serre J. (2003). Diplomatic ceremonial and protocol. Ed. 2. Moscow. International Relations.

6. Cambon J. (1946). Diplomat. Moscow.

7. E. Satow. (1947). Guide to diplomatic practice. Translation by ed. Troyanovskaya A.A. Moscow. Gospolitizdat, OGIZ.

8. Kuzmin E.L. (2005). Diplomatic and business communication: the rules of the game. Moscow. Norma.

9. Tikhomirov M.Yu. (1998). Legal encyclopedia. Moscow.

10. Abdullaeva L. (2005). Features of diplomatic protocol and etiquette: the practice of the Republic of Uzbekistan. Tutorial. Tashkent, Zar Qalam. 
11. Mirkasymov S.M., Rakhimova M.A. (2004). Diplomatic service: theory and practice. A textbook for practitioners dealing with problems of international relations. Tashkent, "Academy".

12. Sutyrin F.D. (2001). Etiquette and diplomatic protocol for everyone. St. Petersburg.

13. M. Farag. (1972). Manual of diplomatic practice. Brussels.

14. The Vienna Convention on Diplomatic Relations of April 18, 1961. https://legal.un.org/ilc/texts/instrumen ts/english/conventions/9_1_1961.pdf

15. The Vienna Convention on Consular Relations of April 24, 1963. https://legal.un.org/ilc/texts/instrumen ts/english/conventions/9_2_1963.pdf

16. Convention on Special Missions of December 8, 1969. https://legal.un.org/ilc/texts/instrumen ts/english/conventions/9_3_1969.pdf

17. Decree of the President of the Republic of Uzbekistan on Organizational Measures for Further Improvement of the Ministry of Foreign Affairs of the Republic of Uzbekistan, No.3654 dated from April 5, 2018. https://lex.uz/ru/docs/361128o\#364671

9. 